\title{
Does land abandonment decrease species richness and abundance of plants and animals in Mediterranean pastures, arable lands and permanent croplands?
}

\author{
Tobias Plieninger ${ }^{1,2}$, Mirijam Gaertner $^{3^{*}}$, Cang Hui ${ }^{3}$ and Lynn Huntsinger ${ }^{4}$
}

\begin{abstract}
Background: Obscured by the more prevalent discussion of intensification and expansion of agricultural land, the impacts of the abandonment of many grasslands and croplands of the world in recent decades have received limited attention in the literature. Land abandonment is a common phenomenon in the Mediterranean Basin, a global biodiversity hotspot, but little is known about the impacts of this process on biodiversity. To upscale existing case-study insight to a Pan-Mediterranean level, we plan to perform a systematic review of the effects of land abandonment on plant and animal richness and abundance in pastures, arable lands and permanent crops of the Mediterranean Basin. In particular, we ask (1) which taxonomic groups are most affected by land abandonment; (2) whether different spatial and temporal scales of studies influence species richness and abundance outcomes; (3) whether previous land use and current anthropogenic impacts on abandoned lands determine differences in the number and abundance of species; and (4) whether landscape context modifies the impacts.

Methods: Our review will be based on searching scientific databases as well as the internet for empirical studies on the effects of land abandonment on biodiversity in the Mediterranean Basin. Study selection follows a three-stage process and includes study quality assessment. Extracted data will be synthesized through meta-analysis. Results will be presented in the form of a quantitative (e.g. figures indicating effect sizes, tables summarizing heterogeneity statistics) and narrative synthesis. Additional aspects will be addressed through meta-regression and sub-group analyses.
\end{abstract}

Keywords: Biodiversity, Land abandonment, Land-use change, Mediterranean agro-ecosystems, Old fields

\section{Background}

Over the past decades, human population growth and increases in per capita consumption of material goods have triggered substantial pressures on global ecosystems [1]. In consequence, land-use change is one important component of global environmental change that is close to irreversibly transgressing planetary limits [2]. Demand for agricultural and forestry commodities has been predicted to continue to grow, thereby increasing the global competition for land [3]. Competition for land as an emergent property of multiple drivers and pressures [4] becomes most prominently evident in the phenomenon of large-scale acquisitions by

\footnotetext{
* Correspondence: gaertnem@gmail.com

${ }^{3}$ Centre for Invasion Biology, Stellenbosch University, Private Bag X1,

Matieland 7602, South Africa

Full list of author information is available at the end of the article
}

foreign states or large corporations (so-called "land grabbing") of around 0.83 million $\mathrm{km}^{2}$ of land (years 2000 to 2010; [5]). Hot spots of competition for land occur at the interfaces between a) forests and agriculture; b) urban land use and intensive agriculture; c) tree plantations and natural forests; d) bioenergy, feed crops and food crops; and e) intensive cropland and extensive agriculture/grazing lands (Lambin and Meyfroidt, in preparation).

The prevailing focus on growing land competition has tended to obscure the fact that the directly opposed process of land abandonment - change towards termination of crop cultivation or livestock grazing that is closely related to intensified land uses elsewhere [6] - has been equally on the rise. Cropland abandonment has affected an estimated 1.47 million $\mathrm{km}^{2}$ worldwide from the $1700 \mathrm{~s}$ to 1992 [7]. Agricultural abandonment has been substantial

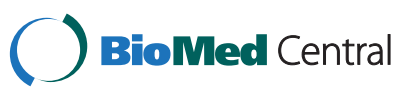


throughout the $20^{\text {th }}$ century in North America, the former Soviet Union and Southern Asia, followed by Europe, South America and China since the 1960s [8]. A set of underlying and proximate ecological (e.g. declining soil fertility), social (rural depopulation) and economic (e.g. globalization of agrocommodity markets, declining farm profitability) drivers determine the patterns and processes of land abandonment, usually through interaction at various spatial and temporal scales [9]. Land abandonment has a range of consequences for the provision of ecosystem processes, including functions and services that are not well-understood and often context-specific, for example on wildfire frequency and intensity, nutrient cycling, carbon sequestration, cultural landscape values and water balance [6].

\section{The Mediterranean Basin as a focus area of land abandoment}

The Mediterranean Basin is one of the world's regions where land abandonment is prevalent $[10,11]$, especially in upland areas [12]. Exact data on land abandonment are not available, but FAO forest statistics indicate that most of the abandoned Mediterranean farmland is in the European Union member countries, Israel, Turkey and Algeria [13]. Most traditional land use systems in the Mediterranean were multiple, fluid and unfixed, lacking sharp boundaries between farmlands, woodlands and fallow lands [14]. Old fields therefore have always been part of a dynamic equilibrium in Mediterranean landscapes, but permanent land abandonment has clearly increased throughout the $20^{\text {th }}$ century. In most northern Mediterranean countries forest cover has increased by about $2 \%$ per annum [15].

Modernization of agricultural production in fertile lowland areas and rural population exodus were probably the most decisive drivers of Mediterranean land abandonment [14]. Agricultural land uses were generally given up when farming practices or structures failed to adjust to changed economic conditions, so that financial revenues declined. Options for adaptation to more intensive, mechanized and profitable farming techniques were particularly limited in the marginal lands of the Mediterranean Basin due to their physical constraints in terms of soils, topography, climate, and remoteness. Small-scale family farms were particularly challenged as they tended to have limited capital for investments. Agricultural policies have further accelerated the concentration of agricultural activities on more fertile and accessible land and the abandonment of marginal lands, though some rural development policies have mitigated this trend $[12,16,17]$. A secondary driver was the large scale exodus of millions of people from the countryside to urban areas and abroad that started in the 1950s. This phenomenon was triggered by the development of booming industries around a few major cities and by guest-worker agreements (e.g., between Greece, Italy, Spain, and Turkey as sending countries and Germany as receiving country), which provided new and better paid job alternatives for rural people. In consequence of this demographic change, farm labor became scarce, and the share of production costs required for labor increased strongly, further weakening farm profitability. Many of the remaining Mediterranean upland farms today have negative net incomes and are sustained by family labor that is valued below the minimum wage [16].

The Mediterranean Basin is one of the first 25 global biodiversity hotspots [18], exhibiting high levels of plant and animal richness and endemism $[15,19,20]$. This rich biodiversity is consequence of a particular biogeography, geological history, landscape ecology and human history. In terms of biogeography, the location at the crossroads of Europe, Asia and Africa brings together species from temperate, arid and tropical regions, exhibiting continuous processes of colonisation and speciation. The turbulent geological evolution of the Mediterranean since the Mesozoic has created many islands, peninsulas and high mountain ranges, providing isolation that generates and maintains particularly high levels of species diversity and endemism. The fine-grained patchwork character of habitats in most Mediterranean landscapes further supports species diversity [15]. Most notably, human land uses have shaped ecosystems for more than 10,000 years and have additionally enhanced biological and landscape diversity $[21,22]$.

Given that the Mediterranean biome has been predicted to experience the greatest proportional change in biodiversity by 2100 , mainly through land use and climate change [23], questions about the impacts of land abandonment on biodiversity are paramount. At the same time, massive local extinctions of species are nothing new for the Mediterranean, in particular for its islands. Here, biotic composition has undergone fundamental transformations with the advent of the Holocene, when humans colonised the islands and removed the relics of Pleistocene and Tertiary flora and fauna [24].

\section{Consequences of Mediterranean land abandonment}

Two fundamentally different biodiversity consequences are possible: On the one hand, Mediterranean land abandonment may contribute to "passive landscape restoration" [25] or "rewilding" [26], thus facilitating the restoration of natural ecosystem processes and reducing human control of landscapes. Several studies confirm that for example woodland bird and large mammal populations have benefited from large-scale land abandonment in various parts of the Mediterranean ([15] and references therein). On the other hand, abandonment of agricultural landscapes may threaten farmland biodiversity, in particular functional diversity [27], associated with anthropogenic landscapes of 
"high nature value" [28,29]. Processes induced by abandonment of agricultural uses that may threaten local plant and animal species richness and abundance include habitat loss, decrease in habitat patchiness, dominance and subsequent competitive exclusion, invasions of non-native plants, litter accumulation, increased predation and increased wildfires [6].

Put into a larger perspective, the dispute between "rewilding" and "high nature value farming" advocates reflects the ongoing scholarly debate of whether biodiversity conservation should pursue "land sparing" (embracing "rewilded" ecosystems) or "land sharing" (calling for the maintenance of "high nature value" farming) [30,31]. But despite the implications of these diverging views for conservation, the biodiversity impacts of land abandonment in the Mediterranean have not been assessed beyond local-scale case studies so far.

\section{Variation in land abandonment impacts}

When assessing the biodiversity impacts of land abandonment, it seems important to consider not only the number of different species, but also their abundances, as diminishing abundance may translate into reduced genetic diversity of populations [32]. The diverging views on the benefits or harm that land abandonment develops on plant and animal populations can partly be explained by the different taxonomic groups (see for example [33] for a comparison between pastures and plantations). Variations in spatial and temporal scales may also contribute to different biodiversity outcomes. For example, studies performed at smaller scales often exhibit stronger impacts than large-scale studies [34]. Further, the temporal dimension is important as plant species richness often increases and shows strong dynamics in the first years after abandonment, but later species composition becomes more stable and species richness decreases [35,36]. Substantially different outcomes can also be expected for the main agricultural systems of the Mediterranean [37]. For example, pastures are generally less disturbed by agricultural activities and closer in species composition to natural ecosystems than arable lands, so that lesser impacts of land abandonment could be expected for pastures [38]. Finally, changes in species richness and abundance may be smaller if the surrounding landscape is predominantly agricultural, while they may be more pronounced if large expanses of surrounding shrubland or woodland provide source populations of woody species that invade the old fields [25]. Also, differences may arise between the four quadrants of the Mediterranean that show contrasting biogeographic properties and land-use intensities [15,39].

\section{Objective of the review}

To upscale existing case-study insights to a PanMediterranean level, we plan to perform a meta-analysis on the effects of land abandonment on plant and animal richness and abundance in pastures, arable lands and permanent crops of the Mediterranean Basin. In particular, we ask (1) which taxonomic groups are most affected by land abandonment, (2) whether different spatial and temporal scales of studies influence species richness and abundance outcomes, (3) whether previous land use and current anthropogenic impacts on abandoned lands determine differences in the number and abundance of species, and (4) whether landscape context acts as an effect modifier. Mediterranean-type environments are particularly suitable for meta-analysis, as they differ less in climate, disturbance regimes and further key aspects than other biome types [40].

The primary question of our review is: Does land abandonment decrease species richness and abundance of plants and animals in Mediterranean pastures, arable lands and permanent crops?

Additionally, we raise the following secondary research questions:

a) Do different taxonomic groups (plants, birds, herpetofauna, mammals, invertebrates) respond differently to land abandonment?

b) Do temporal and spatial scales influence biodiversity outcomes?

- Spatial scale of study (unit of measurement/extent of study area)

- Time elapsed since land was abandoned

c) Does land-use influence biodiversity outcomes?

- Previous land cover (pastures, arable lands, permanent crops)

- Anthropogenic impacts after abandonment (natural succession, afforestation)

d) Does landscape and geographical context influence biodiversity outcomes?

- Surrounding landscape (predominantly farmland, shrubland, woodland)

- Lowland / upland area

- Climate (precipitation, air temperature)

- Quadrant of the Mediterranean Basin (NW, NE, SW, SE)

\section{Methods}

\section{Searches}

Scoping was performed to find optimal keywords and to get a first overview about the availability of suitable studies. The scoping exercise was performed in the ISI 
Table 1 Scoping results

\begin{tabular}{|c|c|c|c|c|}
\hline Keyword 1 & Keyword 2 & & Keyword 3 & Hits \\
\hline Land abandon* & & & & 3136 \\
\hline Land abandon* OR "old fields" & & & & 3790 \\
\hline $\begin{array}{l}\text { Land abandon* OR "old fields" OR } \\
\text { fallow }\end{array}$ & & & & 11294 \\
\hline $\begin{array}{l}\text { Land abandon* OR "old fields" OR } \\
\text { fallow }\end{array}$ & AND "species richness" & & & 439 \\
\hline $\begin{array}{l}\text { Land abandon* OR "old fields" OR } \\
\text { fallow }\end{array}$ & AND species abundance & & & 926 \\
\hline $\begin{array}{l}\text { Land abandon* OR "old fields" OR } \\
\text { fallow }\end{array}$ & $\begin{array}{l}\text { AND Biodiversity OR richness OR abundance OR composition OR } \\
\text { assemblage }\end{array}$ & & & 2420 \\
\hline Land abandon* OR "old fields" & $\begin{array}{l}\text { AND Biodiversity OR richness OR abundance OR composition OR } \\
\text { assemblage }\end{array}$ & AND & Mediterranean & 237 \\
\hline
\end{tabular}

Web of Science, using the various keywords (Table 1). Search terms should refer to population, intervention and outcomes as defined in the primary question and highlighted in Table 2. Based on the scoping exercise, it was decided to perform a search based on the following search string:

(abandon" OR "old fields" OR fallow) AND (Biodiversity OR richness OR abundance OR composition OR assemblage) AND Mediterranean

The following databases will be searched for relevant documents:

\section{ISI Web of Science \\ 2. BIOSIS Previews (Ovid) \\ 3. CABI: CAB Abstracts (Ovid) \\ 4. Scopus \\ 5. ProQuest Agricola \\ 6. ProQuest Dissertations \& Theses}

To locate grey literature, the first 50 pdf and word documents provided by each of the following sources will be considered:

\section{Google Scholar \\ 2. Scirus \\ 3. Dogpile}

This specified search string can be used for searches in databases $1,4,5$, and 6 , and search engines 1 and 2 . It will have to be adapted for databases 2, 3 and search engine 3 . Titles and abstracts will be stored in a single Endnote database and duplicates will be removed. Studies in English, French, Spanish and German language will be considered.

\section{Study inclusion and exclusion criteria}

The selection of studies relevant for this review will take place in a three-stage process. First, relevance for this study will be initially assessed on the basis of study titles. Second, further selection is performed on the basis of paper abstracts. In the third stage, the content of the full papers will be assessed. In cases of doubt, studies will generally be included to the next phase of the selection process. Repeatability of study inclusion will be checked through a random subset of at least $10 \%$ of references whose titles and abstracts will be assessed by another reviewer independently. Inclusion consistency will be calculated through kappa statistics [41]. Selection criteria will be modified if kappa should be below 0.5 . The criteria for inclusion into the review are defined as follows:

\section{Relevant populations}

Plant and animal populations that may change with the abandonment of pastures, arable lands and permanent crops, as defined by the CORINE land cover nomenclature. Pastures are "lands, which are permanently used (at least 5 years) for fodder production. Includes natural or sown herbaceous species, unimproved or lightly improved meadows and grazed or mechanically harvested meadows" [42]. Arable lands refer to "lands under a rotation system used for annually harvested plants and fallow lands, which are permanently or not irrigated" [42]. Permanent crops are understood as "all surfaces occupied by permanent

Table 2 Definition of subject, intervention, outcomes and comparator

\begin{tabular}{llll}
\hline Subject population & Exposure & Outcomes & Comparator \\
\hline $\begin{array}{l}\text { Plant and animal populations that } \\
\text { may change with land }\end{array}$ & $\begin{array}{l}\text { Abandonment } \\
\text { of farming }\end{array}$ & $\begin{array}{l}\text { Change in species } \\
\text { richness or } \\
\text { abandonment }\end{array}$ & $\begin{array}{l}\text { Control plots on adjacent farmland that has not been abandoned } \\
\text { ("space-for-time substitution") or Control plots on farmland before } \\
\text { abandonment ("before-after comparisons") }\end{array}$ \\
\hline
\end{tabular}


crops, not under a rotation system. Includes ligneous crops of standards cultures for fruit production such as extensive fruit orchards, olive groves, chestnut groves, walnut groves shrub orchards such as vineyards and some specific lowsystem orchard plantation, espaliers and climbers" [42]. The geographic scope will be on Mediterranean agroecosystems that are situated within the following countries that form part of the Mediterranean Basin: Albania, Algeria, Bosnia and Herzegovina, Croatia, Cyprus, Egypt, France, Greece, Israel, Italy, Jordan, Lebanon, Libya, Macedonia, Malta, Montenegro, Morocco, Palestine, Portugal, Serbia, Slovenia, Spain, Syria, Tunisia and Turkey.

\section{Relevant exposure}

Complete or partial abandonment of livestock grazing and/or crop cultivation. Only farmland having been abandoned for at least five years will be included. In case multiple years since abandonment have been assessed, the most recent year of measurement will be selected. If a paper reports more than two levels of land abandonment intensity (e.g., "mild" and "complete" abandonment of olive groves), the two exposures with the highest contrast in intensity will be considered.

\section{Relevant comparators}

The review will consider two types of comparators: First, it will make comparisons between species richness and abundance before and after land abandonment of particular sites. Second, it will compare abandoned land to adjacent reference farmland at the same time moment ("space-for-time substitution", [43]).

\section{Relevant outcomes}

Quantitative measures of variables relating to richness or abundance of terrestrial plant and animal species contained on these lands. Only taxonomic groups, not single species abundances will be included. Abandoned farmlands are richer or poorer in species richness or abundance compared to active farmlands or there are no differences.

\section{Relevant types of study design}

Observational field studies and manipulative field experiments. Control plots that are not abandoned should be similar in ecological settings, ideally in the adjacency to abandoned plots.

\section{Potential effect modifiers and reasons for heterogeneity}

The relationship between land abandonment and species richness/abundance may be non-linear over time, exhibiting for example initially increased and later decreased richness/diversity values. Therefore, the time passed since abandonment is a likely source of heterogeneity. Also, considering the time scales involved (60 years and more) it may be difficult to determine the exact period when land abandonment started. Initial farmland conditions (in particular, whether pastures, meadows, cropland or tree-based cropping systems are involved) may modify effects. We also expect heterogeneity between different outcome variables, in particular between different taxonomic groups. The extent of the study area (covering an estimated 1.35 million $\mathrm{km}^{2}$ ) and its variety of physical conditions may introduce additional heterogeneity. Sub-group analyses will be run to explore the impact of some of these factors.

\section{Study quality assessment}

Before data extraction, study quality will be assessed through one reviewer. A subsample will be assessed independently by two reviewers to evaluate consistency. Studies will be categorized according to their quality, following the classification scheme in Table 3. Performance of a meta-analysis requires that only studies that have used controls can be considered. Thus, all studies classified into categories II-2 and above, both experimental and observational, will be included, but qualitative studies will be excluded. Comparisons between adjacent sites would fall into category II-2, while a "before-after" study would be considered II-1 or I, if carried out properly. Our scoping exercise indicates that between site-comparisons are much more frequent than studies of time series. Comprehensive "Before-After-Control-Intervention (BACI)" study designs are very rare, probably due to the enormous practical challenges of carrying out field observations across the elongated time scales (at least 5-10 years) at which land abandonment processes act. The technique of space-for -time substitution, i.e. to infer a temporal trend from a study of different aged sites, is therefore common. The underlying assumption of temporal and spatial variation being equivalent has been under debate, but most studies of long-term phenomena in ecology keep on relying on space-for-time substitution [43].

\section{Table 3 Classification of study quality (Source: [44])}

\begin{tabular}{ll}
\hline Category & Quality of evidence \\
\hline$\|-1$ & $\begin{array}{l}\text { Strong evidence obtained from at least one properly } \\
\text { designed; randomised controlled trial of appropriate size. }\end{array}$ \\
& $\begin{array}{l}\text { Evidence from well designed controlled trials without } \\
\text { randomisation. }\end{array}$ \\
$\|-2$ & $\begin{array}{l}\text { Evidence from a comparison of differences between sites } \\
\text { with and without (controls) a desired species or community. }\end{array}$ \\
Evidence obtained from multiple time series or from \\
dramatic results in uncontrolled experiments. \\
Opinions of respected authorities based on qualitative field \\
evidence, descriptive studies or reports of expert \\
committees. \\
Evidence inadequate owing to problems of methodology e. \\
g. sample size, length or comprehensiveness of monitoring \\
or, conflicts of evidence.
\end{tabular}




\section{Data extraction strategy}

All richness and abundance measures will be extracted where multiple parameters are given. If necessary, summary statistics will be extracted from tables and graphs, using image analysis software. If original data are provided but summary statistics are lacking, summary statistics will be calculated on the basis of raw data. Information to answer the secondary questions will also be extracted. Location data may be used to obtain parameter estimates from other data sources (e.g. use of GoogleEarth or CORINE data for an estimate of surrounding landscape features). In cases of insufficient information, corresponding authors will be contacted to gather the required data.

All information will be entered in spreadsheets. Spreadsheet categories will be pretested to guarantee repeatability. The following information will be extracted:

\section{Response variables:}

- Species richness: mean, standard deviation or standard error, df or sample size, statistics (e.g., t, z, $\left.F, X^{2}\right)$

- Species $(\alpha)$ abundance: mean, standard deviation or standard error, df or sample size, statistics (e.g., t, z, $\left.\mathrm{F}, \mathrm{X}^{2}\right)$

- Taxa (Plants [annuals, forbs, grasses, woody species], birds, mammals, amphibians, reptiles, arthropods [bees, bugs, carabids, hoverflies, spiders])

- Exact description of variable measured: e.g. "bee diversity", "species richness of native plants"

\section{Independent variables:}

- Sample unit size $\left(\mathrm{m}^{2}\right)$

- Extent of study area $\left(\mathrm{km}^{2}\right)$

- Time elapsed since land was abandoned (in years)

- Previous land cover (pasture, arable land, permanent crop)

- Anthropogenic impacts after abandonment (natural succession, afforestation, some form of forest management)

- Surrounding landscape (predominantly farmland, shrubland, woodland)

- Quadrant of the Mediterranean Basin (NW, NE, SW, SE)

- Country

- Altitude above sea level (in m)

- Mean annual precipitation (in $\mathrm{mm}$ )

- Mean annual temperature (in ${ }^{\circ} \mathrm{C}$ )

\section{Data synthesis and presentation}

Data will be synthesized through meta-analysis to address the primary questions. Secondary questions and additional aspects will be addressed through meta-regression and sub-group analyses. The comprehensive meta-analysis software (CMA version 2.0) will be used to conduct a two-group comparison (abandoned versus reference sites) with additional moderators as defined as secondary questions in section 2.2. Cohen's [45] mean difference effect size, $g[46,47]$ and a mixed (random) effects model will be applied. A two-tail Z-test will be performed to examine the null hypothesis (i.e., the effect size equals zero) and a Q-test for the heterogeneity analysis. The search strategy includes both peer-reviewed sources and "grey literature", but some publication bias may remain. Therefore, possible publication bias will be examined through funnel plots [48]. Results will be presented in the form of a quantitative (e.g. figures indicating effect sizes, tables summarizing heterogeneity statistics) and narrative synthesis of all included studies. A similar approach has been taken by some of the co-authors (MG, $\mathrm{CH}$ ) in a previous study on the impacts of alien plant invasions on species richness in Mediterranean-type ecosystems [34].

\section{Competing interests}

The authors declare that they have no competing interests.

\section{Authors' contributions}

TP and MG conceived of the study, coordinated development of the protocol and drafted the manuscript. $\mathrm{CH}$ and $\mathrm{LH}$ participated in development of the protocol and drafting of the manuscript. All authors read and approved the final manuscript.

\section{Acknowledgements}

T.P. is funded by the German Ministry of Education and Research (FKZ 01UU0904A). The funding source is not involved in study design, in the collection, analysis and interpretation of data, in the writing of the report and in the decision to submit the article for publication. The Editor-in-Chief and two anonymous referees provided valuable advice.

\section{Author details}

${ }^{1}$ Ecosystem Services Research Group, Berlin-Brandenburg Academy of Sciences and Humanities, Jägerstr. 22/23, 10117, Berlin, Germany. ${ }^{2}$ Geography Department, Humboldt-Universität zu Berlin, 10099, Berlin, Germany. ${ }^{3}$ Centre for Invasion Biology, Stellenbosch University, Private Bag X1, Matieland 7602, South Africa. ${ }^{4}$ Department of Environmental Science, Policy, and Management, University of California, 130 Mulford Hall MC 3114, Berkeley, CA 94720-3114, USA.

Received: 16 November 2012 Accepted: 13 February 2013 Published: 16 February 2013

\section{References}

1. Foley JA, DeFries R, Asner GP, Barford C, Bonan G, Carpenter SR, Chapin FS, Coe MT, Daily GC, Gibbs HK, et al: Global consequences of land use. Science 2005, 309:570-574

2. Rockstrom J, Steffen W, Noone K, Persson A, Chapin FS, Lambin EF, Lenton TM, Scheffer M, Folke C, Schellnhuber HJ, et al: A safe operating space for humanity. Nature 2009, 461:472-475.

3. Lambin EF, Meyfroidt P: Global land use change, economic globalization, and the looming land scarcity. Proc Natl Acad Sci U S A 2011, 108:3465-3472.

4. Smith P, Gregory PJ, van Vuuren D, Obersteiner M, Havlik P, Rounsevell M, Woods J, Stehfest E, Bellarby J: Competition for land. Philos Trans R SoC Lond B Biol Sci 2010, 365:2941-2957.

5. Anseeuw W, Boche M, Breu T, Giger M, Lay J, Messerli P, Nolte K: Transnational Land Deals for Agriculture in the Global South. Analytical Report 
based on the Land Matrix Database. Bern, Montpellier, Hamburg: CDE, CIRAD, GIGA; 2012

6. Rey Benayas JM, Martins A, Nicolau JM, Schulz JJ: Abandonment of agricultural land: an overview of drivers and consequences. $C A B$ Reviews: Perspectives in Agriculture, Veterinary Science, Nutrition and Natural Resources 2007, 2:57.

7. Ramankutty N, Foley JA: Estimating historical changes in global land cover: Croplands from 1700 to 1992. Global Biogeochem Cycles 1999, 13:997-1027.

8. Cramer VA, Hobbs RJ, Standish RJ: What's new about old fields? Land abandonment and ecosystem assembly. Trends Ecol Evol 2008, 23:104-112.

9. Hobbs RJ, Cramer VA: Why old fields? Socioeconomic and ecological causes and consequences of land abandonment. In Old Fields: Dynamics and Restoration of Abandoned Farmland. Edited by Cramer VA, Hobbs RJ. Washington DC: Island Press; 2007:1-14.

10. Weissteiner CJ, Boschetti M, Bottcher K, Carrara P, Bordogna G, Brivio PA: Spatial explicit assessment of rural land abandonment in the Mediterranean area. Glob Planet Chang 2011, 79:20-36.

11. Sluiter $R$, de Jong SM: Spatial patterns of Mediterranean land abandonment and related land cover transitions. Landsc Ecol 2007, 22:559-576.

12. MacDonald D, Crabtree JR, Wiesinger G, Dax T, Stamou N, Fleury P, Lazpita $J G$, Gibon A: Agricultural abandonment in mountain areas of Europe: Environmental consequences and policy response. J Environ Manage 2000, 59:47-69.

13. Mazzoleni S, di Pasquale G, Mulligan M, di Martino P, Rego F: Recent dynamics of the Mediterranean vegetation and landscape. Chichester, West Sussex; Hoboken, NJ: John Wiley \& Sons; 2004.

14. Papanastasis VP: Land abandonment and old field dynamics in Greece. In Old Fields: Dynamics and Restoration of Abandoned Farmland. Edited by Cramer VA, Hobbs RJ. Washington DC: Island Press; 2007:225-246.

15. Blondel J, Aronson J, Bodiou J-Y, Boef G: The Mediterranean Region: Biological Diversity in Space and Time. 2nd edition. Oxford, New York: Oxford University Press; 2010.

16. Keenleyside C, Tucker GM: Farmland Abandonment in the EU: an Assessment of Trends and Prospects. Report prepared for WWF. London: Institute for European Environmental Policy; 2010.

17. Renwick A, Jansson T, Verburg PH, Revoredo-Giha C, Britz W, Gocht A, McCracken D: Policy reform and agricultural land abandonment in the EU. Land Use Policy 2013, 30:446-457.

18. Myers N, Mittermeier RA, Mittermeier CG, da-Fonseca GAB, Kent J: Biodiversity hotspots for conservation priorities. Nature 2000, 403:853-858.

19. Cuttelod A, García N, Abdul Malak D, Temple H, Katariya V: The Mediterranean: a biodiversity hotspot under threat. In The 2008 Review of The IUCN Red List of Threatened Species. Edited by Vié J-C, Hilton-Taylor C, Stuart SN. Gland: IUCN; 2008.

20. Underwood EC, Viers JH, Klausmeyer KR, Cox RL, Shaw MR: Threats and biodiversity in the Mediterranean biome. Divers Distrib 2009, 15:188-197.

21. Grove AT, Rackham O: The Nature of Mediterranean Europe: An Ecological History. New Haven, London: Yale University Press; 2001.

22. Bugalho MN, Caldeira MC, Pereira JS, Aronson J, Pausas JG: Mediterranean cork oak savannas require human use to sustain biodiversity and ecosystem services. Front Ecol Environ 2011, 9:278-286.

23. Sala OE, Chapin FS, Armesto JJ, Berlow E, Bloomfield J, Dirzo R, HuberSanwald E, Huenneke LF, Jackson RB, Kinzig A, et al: Global biodiversity scenarios for the year 2100. Science 2000, 287:1770-1774.

24. Alcover JA, Seguí B, Bover P: Extinctions and local disappearances of vertebrates in the Western Mediterranean Islands. In Extinctions in Near Time Causes, Contexts, and Consequences. Edited by MacPhee RDE. New York: Kluwer Academic Publishers; 1999:165-188.

25. Bowen ME, MCAlpine CA, House APN, Smith GC: Regrowth forests on abandoned agricultural land: A review of their habitat values for recovering forest fauna. Biol Conserv 2007, 140:273-296.

26. Navarro LM, Pereira HM: Rewilding abandoned landscapes in Europe. Ecosystems 2012, 15:900-912.

27. Peco B, Carmona CP, de Pablos I, Azcarate FM: Effects of grazing abandonment on functional and taxonomic diversity of Mediterranean grasslands. Agric Ecosyst Environ 2012, 152:27-32.
28. Oppermann R, Beaufoy G, Jones G: High Nature Value Farming in Europe - 35 European Countries, Experiences and Perspectives. Ubstadt-Weiher: Verlag Regionalkultur; 2012

29. Sirami C, Brotons L, Burfield I, Fonderflick J, Martin JL: Is land abandonment having an impact on biodiversity? A meta-analytical approach to bird distribution changes in the north-western Mediterranean. Biol Conserv 2008, 141:450-459.

30. Tscharntke T, Clough Y, Wanger TC, Jackson L, Motzke I, Perfecto I, Vandermeer J, Whitbread A: Global food security, biodiversity conservation and the future of agricultural intensification. Biol Conserv 2012, 151:53-59.

31. Phalan B, Onial M, Balmford A, Green RE: Reconciling food production and biodiversity conservation: Land sharing and land sparing compared. Science 2011, 333:1289-1291.

32. Davis MA: Invasion Biology. Oxford, New York: Oxford University Press; 2009

33. Felton $A$, Knight $E$, Wood J, Zammit C, Lindenmayer D: A meta-analysis of fauna and flora species richness and abundance in plantations and pasture lands. Biol Conserv 2010, 143:545-554.

34. Gaertner M, Den Breeyen A, Hui C, Richardson DM: Impacts of alien plant invasions on species richness in Mediterranean-type ecosystems: a metaanalysis. Prog Phys Geogr 2009, 33:319-338.

35. Lavorel S, Lepart J, Debussche M, Lebreton JD, Beffy JL: Small-scale disturbances and the maintenance of species-diversity in Mediterranean old fields. Oikos 1994, 70:455-473.

36. Gondard H, Romane F, Grandjanny M, Li JQ, Aronson J: Plant species diversity changes in abandoned chestnut (Castanea sativa) groves in southern France. Biodivers Conserv 2001, 10:189-207.

37. Bonet A, Pausas JG: Old field dynamics on the dry side of the Mediterranean Basin: Patterns and processes in semiarid Southeast Spain. In Old Fields: Dynamics and Restoration of Abandoned Farmland. Edited by Cramer VA, Hobbs RJ. Washington DC: Island Press; 2007:247-264.

38. Batary P, Andras B, Kleijn D, Tscharntke T: Landscape-moderated biodiversity effects of agri-environmental management: a meta-analysis. Proc Biol Sci 2011, 278:1894-1902.

39. Deil U: Characters of "traditional" and "modern" vegetation landscapes a comparison of northern Morocco and southern Spain. Phytocoenologia 2003, 33:819-860

40. Pauchard A, Cavieres LA, Bustamante RO: Comparing alien plant invasions among regions with similar climates: where to from here? Divers Distrib 2004, 10:371-375.

41. Cohen J: A coefficient of agreement for nominal scales. Educ Psychol Meas 1960, 20:37-46.

42. Bossard M, Feranec J, Otahel J: CORINE land cover technical guide - Addendum 2000. Technical report No 40. Copenhagen: European Environment Agency; 2000.

43. Pickett STA: Space-for-time substitution as an alternative to long-term studies. In Long-term Studies in Ecology: Approaches and Alternatives. Edited by Likens GE. New York: Springer; 1989.

44. Pullin AS, Knight TM: Support for decision making in conservation practice: an evidence-based approach. J Nat Conserv 2003, 11:83-90.

45. Cohen J: Statistical Power Analysis for the Behavioral Sciences. 2nd edition. Hillsdale: L. Erlbaum Associates; 1988.

46. Borenstein $\mathrm{M}$, Hedges L, Higgins J, Rothstein H: Comprehensive Meta-Analysis, Version 2. Englewood: Biostat; 2005.

47. Lipsey MW, Wilson DB: Practical Meta-analysis. Thousand Oaks: Sage Publications; 2001

48. Centre for Evidence-Based Conservation: Guidelines for Systematic Review in Environmental Management. Version 4.0. Environmental Evidence. 2010 [www. environmentalevidence.org/Authors.htm]

doi:10.1186/2047-2382-2-3

Cite this article as: Plieninger et al:: Does land abandonment decrease species richness and abundance of plants and animals in Mediterranean pastures, arable lands and permanent croplands?. Environmental Evidence 2013 2:3. 